\title{
Ensuring water supply for all towns and villages in the Eastern Cape and Western Cape Provinces of South Africa
}

\author{
ER Hay ${ }^{1}, \mathrm{~K}$ Riemann ${ }^{1 *}, \mathrm{G}$ van Zy|${ }^{2}$ and I Thompson ${ }^{3}$ \\ ${ }^{1}$ Umvoto Africa (Pty) Ltd, PO Box 61, Muizenberg, Cape Town, Western Cape, South Africa \\ ${ }^{2}$ Gerrit van Zyl Independent Consultant, 1 Fynbos Street, Protea Valley, Bellville, South Africa \\ ${ }^{3}$ Department of Water Affairs, D: National Water Resource Planning, Private Bag X313, Pretoria, South Africa
}

\begin{abstract}
The Department of Water Affairs (DWA) has embarked on a nationwide programme to develop water-reconciliation strategies for all towns across the country. Reconciliation strategies for the major metropolitan areas and systems (e.g. Johannesburg/Pretoria, East London, Cape Town and Durban) were developed next. The implementation of these strategies is monitored by strategy steering committees. The approach has now been extended to all other metropolitan areas as well as all towns and villages or clusters of villages. In order to prepare the actual strategies, regardless of the size of the town, thorough documentation, research and analysis of the available information was required, as well as evaluation of projected growth scenarios to assess water requirements over the next 25 years and identification of potential additional sources to meet this growing requirement. It has emerged that the poor operation and maintenance of water supply, treatment and reticulation infrastructure are resulting in significant losses, which, if corrected, can reverse the current water shortages being experienced. Similarly, the generally poor management of effluent remains a threat to surface water and groundwater quality downstream. It appears that many municipalities perceive groundwater as an unreliable resource; however, in general, the issue of staff and skills shortages to manage the resource effectively is the actual problem. This is an operational issue rather than a groundwater-resource-specific issue. This aspect requires special attention for existing groundwater schemes and proposed groundwater development. In most instances water conservation and water-demand management and the development of local surface and groundwater resources are the most feasible options to meet any current or projected future water-supply shortfalls. Any intervention must be combined with a skills-development programme at the operational level to ensure the sustainability of the proposed supply options. This paper is based on the experience gained in the development of reconciliation strategies for the towns and villages in the DWA Southern Planning Region (i.e. surface water drainage areas in the Eastern Cape and Western Cape Provinces), which was carried out by Umvoto Africa in association with engineering consulting practice Aurecon.
\end{abstract}

Keywords: water supply, water reconciliation, groundwater options, operation and maintenance, water conservation and water demand management

\section{All towns reconciliation strategies study}

In 2008 the Department of Water Affairs (DWA) commenced with a nationwide programme to develop water reconciliation strategies for all towns, villages and clusters of villages across the country, following on the good progress with the reconciliation strategies for the metropolitan areas. The overall objective of the studies was to provide first-order water availability and water requirement reconciliation strategies for all towns and villages in South Africa (DWA, 2009b). The large numbers of rural villages that occur in the eastern regions of the Eastern Cape Province part of the study area were grouped as clusters to facilitate integrated water resource management rather than the development of a huge numbers of stand-alone schemes. Towns and clusters of villages were studied in order of priority in terms of their currently perceived water resource problems.

The main objectives of the study were to:

- Identify towns with an immediate need for high-intensity reconciliation studies

This paper was originally presented at the International Conference on Groundwater: Our Source of Security in an Uncertain Future, Pretoria, 19-21 September 2011.

* To whom all correspondence should be addressed.

象 +27 21709 6700; fax: +27 86524 0001; e-mail:kornelius@umvoto.com
- Identify towns that do not need any water resource development interventions within the 25-year timeframe of the reconciliation strategies

- Provide first-order reconciliation strategies for all towns

- Support the DWA Regional Offices and Water Services Authorities (WSAs) with information related to water resources of all the towns and villages

- Provide information that can be included in regional and national water resource planning instruments such as the National Water Resource Strategy (NWRS) developed by DWA and catchment management strategies (CMSs) developed by CMAs

- Provide information that can be included in planning instruments of local government to aid their alignment of local development plans and policies (e.g. Water Services Development Plans (WSDPs), Integrated Development Plans (IDPs) and Spatial Development Frameworks (SDFs)) to national and regional strategies (e.g. NWRS, CMSs).

The study was undertaken from a water-resource perspective that took into consideration the overall scarcity of water in South Africa and the high cost of water transfer. Therefore each strategy was developed in a template that provides an overview of the current situation, the current water resources, the existing bulk and reticulation infrastructure, the percentage of non-revenue water it produces and the scoring in terms of DWA's Blue and Green Drop certification process in order 
ANNUAL REQUIREMENT SCENARIOS VERSUS CURRENT AND POTENTIAL YIELDS

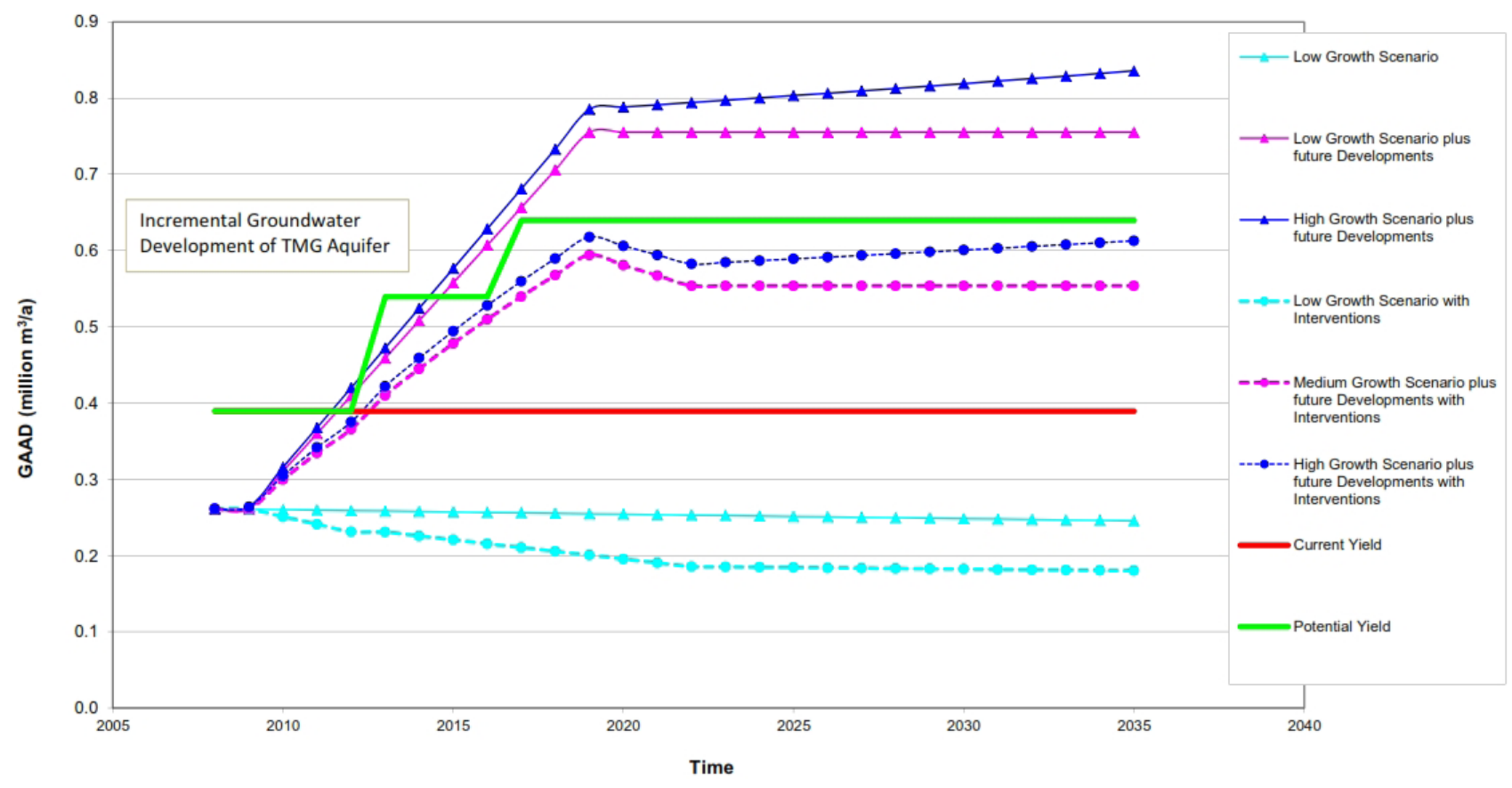

Figure 1

Example of water-reconciliation scenarios until 2035, showing low-, medium- and high-growth water-requirement scenarios, current yield of water supply, possible reduction in water requirements due to water conservation, and water-demand management interventions and possible augmentation options to meet the high-growth scenario

to identify whether a town, village or cluster of villages has a water-resource or a water-service problem. The recommendations provide a list of the suitable interventions to address any current or future water supply shortfalls. In most instances water conservation and water demand management and the development of local surface and groundwater resources were the most feasible options to meet any current or projected future water supply shortfalls.

It was not considered feasible or necessary to develop an individual reconciliation strategy for each individual town or settlement, but all towns and villages were addressed in the study. Towns, villages and settlements were grouped together into logical clusters based on their current or proposed future shared water resources for which a single reconciliation strategy could be developed.

The current water balance (see Fig. 1) and the water-infrastructure situation were established for each town or cluster of towns and villages, based on the available information. Data gaps which could not be filled from current information sources were identified and marked in the strategies for attention. Towns with a significant water-supply shortfall or data gaps beyond the scope of this study and/or requiring separate attention were 'red-flagged' for a detailed reconciliation study or further follow-up to improve the confidence in the information.

\section{Current situation of water supply at local municipal level}

There has been a major emphasis in the past decade in addressing the backlogs in water-supply infrastructure in the informal suburbs of urban towns, and in rural areas, with many rural water-supply schemes having been commissioned. These schemes include both surface-water and groundwater supplies throughout the rural areas. The overall impression of the current situation of water supply at local municipal level while doing the study is discussed below in terms of several relevant aspects.

\section{Water requirements}

The water requirements of communities and towns vary significantly throughout the study area, depending upon factors such as the climatic conditions, level of service, socio-economic situation, wet industries, institutional capacity and consumer behaviour. However, there are several guidelines on what constitutes an acceptable level of water consumption. The basic water services are defined in South Africa as $25 \mathrm{\ell} / \mathrm{d}$ per person (RSA, 2001), which equals the accepted norm for free basic water of $6 \mathrm{k} \ell /$ month for a household of 8 persons. The DWA recommendations for low-income housing are $60 \ell / d$ per person for planning purposes, while the water requirements in more affluent, developed towns can easily increase up to $250 \mathrm{l} / \mathrm{d}$ per person. The dynamics of water use for each town may differ, but for the purposes of this study the towns have been categorised with respect to size and locality. This categorisation is considered adequate to cover the majority of the towns in the Eastern and Western Cape. Table 1 presents the categorisation of per capita water requirements for each type of town (DWA, 2009b).

Based on these recommended water-requirement scenarios, the theoretical average water requirement for domestic use is $\sim 110$ million $\mathrm{m}^{3} / \mathrm{a}$ and $\sim 210$ million $\mathrm{m}^{3} / \mathrm{a}$ in the Western Cape and Eastern Cape, respectively, excluding the metropolitan areas. However, the actual water consumption seems to be significantly higher due to some towns having a per capita use of more than $400 \ell / d$ per person, especially the coastal holiday towns along 


\begin{tabular}{|l|c|}
\hline \multicolumn{2}{|c|}{ Table 1 } \\
Average per capita water requirements for different categories of settlements
\end{tabular}

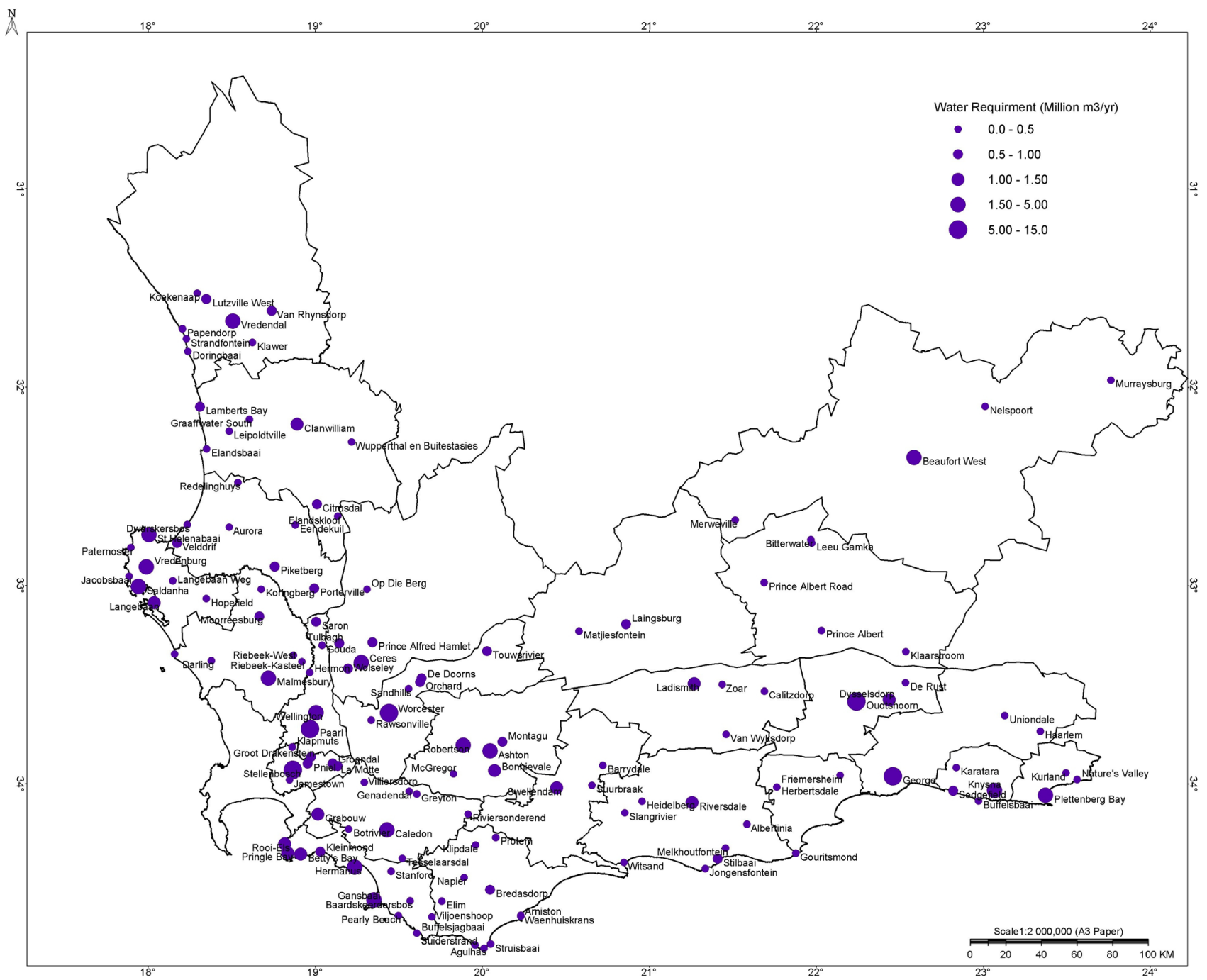

Figure 2

Map of towns in the Western Cape, indicating the current water requirements

the Southern Cape coast, and other towns having significant water losses (Table 2). The data on actual water consumption need to be improved with good metering programmes, as this information is not readily available for most of the municipalities. The current, actual or estimated water requirements for the towns in the Western Cape are indicated in Fig. 2.

\section{Water losses}

Due to a lack of reliable data on water consumption, the calculated bulk-water requirements are in most cases based on theoretical requirements. However, the water losses (either measured or calculated) are very high in many towns and in many instances no strategies have been developed or implemented by the municipalities for water conservation and waterdemand management to address the water losses and to reduce the water requirements.

In addition, the local schemes are often operated without having operation and maintenance (O\&M) plans or droughtresponse plans in place. Water-supply interruptions are addressed when they happen. Hence, any failure of scheme components or changing weather pattern results in water shortages that could easily have been avoided. It has been recognised in several previous studies that failure of groundwater 


\begin{tabular}{|l|c|c|c|c|}
\hline \multicolumn{5}{|c|}{$\begin{array}{c}\text { Table 2 } \\
\text { Examples of calculated water losses (unaccounted for water (UAW)) } \\
\text { in selected towns in the Eastern and Western Cape }\end{array}$} \\
\hline Town & Population & $\begin{array}{c}\text { Water } \\
\text { consumption }\end{array}$ & \multicolumn{2}{c|}{ Unaccounted for water } \\
\hline & & Million m $^{3 / a}$ & Million m $^{3 / a}$ & $\%$ \\
\hline Adelaide & 10500 & 0.727 & 0.43 & 60 \\
\hline Bedford & 13250 & 0.526 & 0.12 & 22 \\
\hline Alice, Middeldrift & 52000 & 3.67 & 1.15 & 57 \\
\hline Stutterheim & 14400 & 1.29 & 0.56 & 44 \\
\hline Mthatha and surrounds & 230000 & 22.1 & $\sim 12.0$ & 55 \\
\hline Tulbagh & 7000 & 0.79 & 0.42 & 45 \\
\hline Beaufort West & 33300 & 2.5 & 1.3 & 52 \\
\hline Ashton & 13900 & 2.19 & 1.24 & 57 \\
\hline Plettenberg Bay & 33500 & 3.43 & 1.50 & 44 \\
\hline Bitterfontein & 2900 & 0.13 & 0.07 & 55 \\
\hline
\end{tabular}

\begin{tabular}{|c|c|c|c|c|}
\hline \multicolumn{5}{|c|}{$\begin{array}{c}\text { Table } 3 \\
\text { Blue Drop and Green Drop scores for selected municipalities (Department of Water } \\
\text { Affairs, 2011a, 2011b) }\end{array}$} \\
\hline Municipality & \begin{tabular}{|l|} 
Water quality \\
compliance
\end{tabular} & Blue Drop & $\begin{array}{c}\text { Effluent } \\
\text { quality }\end{array}$ & Green Drop \\
\hline George LM & Good & $96 \% *$ & Good & $91 \% *$ \\
\hline Bitou LM & Good & $96 \% *$ & Good & $96 \% *$ \\
\hline Eden DM area (excl towns) & Poor / Fair & $19 \%$ & Poor & $8 \%$ \\
\hline Cederberg LM & Fair & $51 \%$ & Poor & $63 \%$ \\
\hline Matzikama LM & Poor / Fair & $33 \%$ & Fair / Good & $66 \%$ \\
\hline Amathole DM overall & Fair / Good & $65.2 \%$ & Poor / Fair & $56 \%$ \\
\hline ADM rural borehole schemes & Fair & $24 \%$ & \multicolumn{2}{|c|}{ Not applicable } \\
\hline Ikwezi LM & Poor & $26 \%$ & Poor & $2 \%$ \\
\hline Kouga LM & Poor / Good & $75 \%$ & Poor & $36 \%$ \\
\hline Koukamma LM & Poor / Fair & $14 \%$ & Poor & $14 \%$ \\
\hline Cacadu DM rural schemes & Poor / Fair & $18 \%$ & \multicolumn{2}{|c|}{ Not applicable } \\
\hline
\end{tabular}

schemes can in most cases be attributed to a lack of effective operation and maintenance.

It appears from the analysis of the information gathered during the All Towns Reconciliation Strategy Study that at least $34 \times 10^{6} \mathrm{~m}^{3}$ of water is lost in the Western Cape alone (excluding Cape Town and surrounds) each year between the water resource and the end-user, of which more than $10 \mathrm{x}$ $10^{6} \mathrm{~m}^{3} / \mathrm{a}$ could easily be saved through the implementation of effective water conservation and water demand management measures (DWA, 2011e). This would be sufficient to meet the annual water requirements of a town such as George or Stellenbosch. The situation in the Eastern Cape is worse with several examples of towns where $50 \%$ and more of the water abstracted does not reach the end-users (see Table 2). In cases without measured abstraction and consumption data, acceptable water losses of $15 \%$ to $20 \%$ have been assumed. This stresses the need for a good metering programme to better manage water and finances in every municipality.

The examples of high water losses in Table 2 are calculated water losses (or unaccounted for water, UAW) for selected towns in the Eastern and Western Cape, based on measured data and or observations. These are always non-revenue water and a loss of income to the municipality due to the cost of purification, reticulation and operation that was spent and a loss in revenue that was not collected from the users.

\section{Water quality}

Water quality of the resource and the drinking water is of concern throughout the study area with many communities relying on untreated raw water from rivers, springs or boreholes. Many of these sources, especially in the vast rural areas of the Eastern Cape, are contaminated due to a lack of proper land management and source protection.

The Blue Drop Report (DWA, 2011a) provides details of the drinking-water quality situation for towns and supply areas that are served from a water treatment works (WTWs). The smaller stand-alone water-supply and treatment schemes may achieve the required drinking water quality standard but often lack the required water-quality management to ensure continuously good drinking water quality (see Table 3 ). This is partly due to a lack of water-quality monitoring at the source to identify water contamination. Most of the small stand-alone schemes supply water without any treatment, and without water-quality 


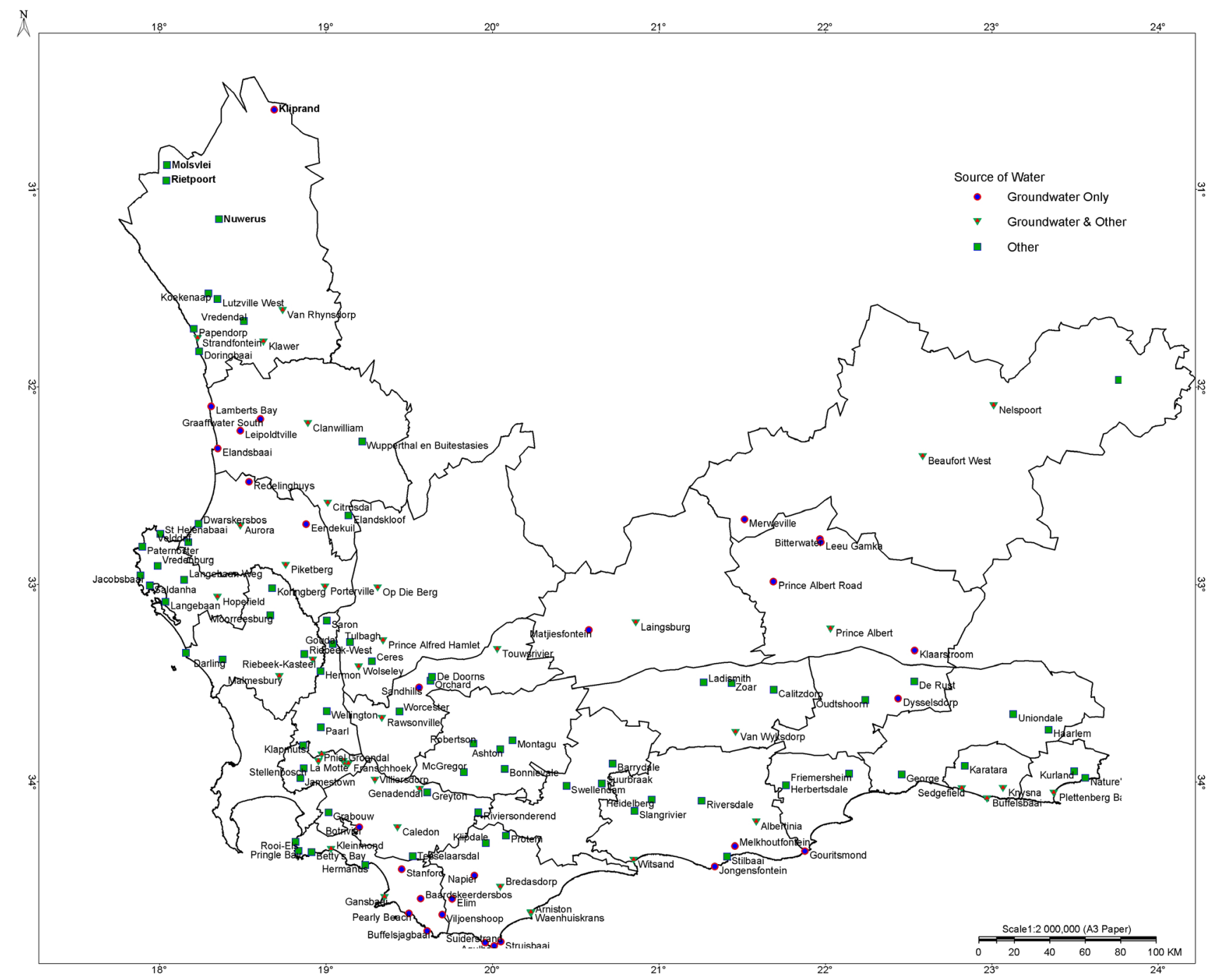

Figure 3

Map of towns in the Western Cape, indicating their water-supply source; (a) groundwater as sole source of supply; (b) groundwater and surface water; (c) surface water and/or other

monitoring. Hence, it is to be expected that the situation is worse than indicated in Table 3.

The situation for the wastewater treatment works (WWTWs) is even bleaker in many instances, with many works not complying with effluent quality standards. It seems that with few exceptions only the metropolitan areas and bigger towns achieved acceptable Green Drop scores (see Table 3). The non-compliance with effluent water quality standards results in the risk of pollution to water resources that are potential water sources for users downstream.

In most cases, the poor condition of WTWs and WWTWs can be attributed to neglect or delay in applying proper operation and maintenance. The aforementioned refers only to the supply areas that have treatment works for water supply or sanitation services. The majority of the population in the rural areas does not have access to treated water and or to adequate sanitation services, which creates both a health problem for the population and a risk of water pollution. Monitoring data of selected rural boreholes in the Eastern Cape indicate the serious level and extent of the groundwater pollution with microbiological pollutants (DWA, 2012), mainly due to inadequate land-use management practices.

\section{Surface water use}

Surface water has historically been the most important water resource for South African towns. Settlements that became towns over time were established in the vicinity of a water source. Except for the drier parts of the country, this was mostly where enough free-flowing surface water was available at that time. Surface-water storage dams and groundwater were used much later.

\section{Groundwater use}

Groundwater has historically been given limited attention, and has not been perceived as an important water resource in South Africa. This is reflected in general statistics showing that only $13 \%$ of the nation's total water supply originates from groundwater. Public perception prevails that groundwater is not a sustainable resource for bulk domestic supply and cannot be managed properly. Despite this, a growing number of municipalities utilise groundwater on a regular basis, and provide examples of successful management of this resource (Riemann et al., 2011). 


\begin{tabular}{|c|c|c|c|c|c|}
\hline \multicolumn{6}{|c|}{$\begin{array}{c}\text { Table } 4 \\
\text { Water supply sources used in municipalities in the Eastern and Western Cape } \\
\text { (No. of towns, excluding metropolitan areas) }\end{array}$} \\
\hline \multirow[t]{2}{*}{ District Municipality } & \multicolumn{2}{|c|}{ Groundwater } & \multicolumn{2}{|c|}{ Surface water } & \multirow[t]{2}{*}{ Other } \\
\hline & Total & Sole source & Total & Sole source & \\
\hline Alfred Nzo* & 3 & 1 & 4 & 1 & \\
\hline Amathole* & 12 & 5 & 27 & 16 & \\
\hline Cacadu & 34 & 24 & 33 & 22 & 2 \\
\hline Chris Hani* & 10 & 9 & 10 & 6 & \\
\hline OR Tambo* & 4 & 1 & 11 & 5 & \\
\hline Cape Winelands & 4 & 1 & 24 & 12 & \\
\hline Central Karoo & 8 & 5 & 5 & 2 & 1 \\
\hline Eden & 13 & 9 & 39 & 21 & 4 \\
\hline Overberg & 16 & 10 & 25 & 16 & \\
\hline West Coast & 20 & 15 & 37 & 28 & 1 \\
\hline
\end{tabular}

Due to the fact that most groundwater schemes are not properly managed and monitored, it is not possible to derive the total yield and or usage of the currently existing groundwater-supply schemes. A rough estimate of the known yield of groundwater schemes in the Western Cape shows that about $10 \%$ of the total yield in the Western Cape currently stems from groundwater, which compares well to the national average of $8 \%$ to $13 \%$ (DWAF, 2008).

The comparison of the number of towns, relying on groundwater as their major or sole source of water, with towns that utilise other sources of water, shows a different picture and illustrates the increasingly important role that groundwater plays in ensuring an adequate water supply to towns and villages (see Table 4). The large number of towns relying on a single water resource as sole source for their water supply is of particular concern, as this increases the vulnerability of municipalities to climate- and infrastructure-related disasters, such as droughts, floods and infrastructure failure. Hence, it is recommended to develop alternative sources for their water supply, where this is feasible, and move towards conjunctive-use scenarios in order to limit their vulnerability to natural disasters.

The Groundwater Resource Information Project (GRIP) recently undertaken by DWA in the Eastern Cape confirms the importance of groundwater for rural water supply (DWA, 2009a). More than half of the visited and surveyed communities across the Eastern Cape are supplied by groundwater from more than 2000 boreholes. At this stage the GRIP project covered only a part of the rural area of the Eastern Cape. A database with all water-supply infrastructure in the Eastern Cape (DWA, 2011c) has about 10000 entries for boreholes that presumably are used by the respective communities.

The All Towns Reconciliation Strategy Study provided the groundwater potential for each municipality at a local scale and identified possible target aquifers in the vicinity of the towns, where this appears to be feasible (DWA, 2011d, 2011e). Groundwater development was recommended for about $50 \%$ of the towns and village clusters in the Eastern Cape and Western Cape as the next intervention, after the implementation of water conservation and water demand management measures. This indicates the significant contribution that groundwater can and should play for domestic water supply.

\section{Common issues}

A number of common issues across municipalities were identified that impact negatively on the water supply and service delivery at local municipality level. Most of these are institutional issues related to a lack of the required technical skills and a lack of proper management of water infrastructure and water resources. The resulting issues can be summarised as:

- Lack of operation and maintenance of existing schemes

- Deterioration of water infrastructure

- Poor drinking water and waste water quality

- High water losses

It appears that municipalities tend to prefer the development of bigger regional water-supply schemes, as they perceive the O\&M of such a scheme to be easier and more cost-effective than the O\&M required for a large number of stand-alone schemes. Although their reasoning is quite understandable, the solution does not lie in reducing the number of schemes but rather in skills development and capacity building for the technical staff required at the operational level.

\section{Proposed interventions}

A number of towns and most of the villages in the rural areas already experience a shortfall in water supply, as their current supply infrastructure cannot meet the water requirements. This will be exacerbated in 20 or 30 years to come, as the water requirements will increase due to population growth, economic development and the envisaged improvement in service levels for most rural and peri-urban communities.

In order to alleviate the shortfall in water supply and to allow for the required upgrades in the level of water services in some of the towns and the rural villages, several local intervention options are available, e.g.:

- Implementation of water conservation and water demand management measures to reduce losses and wastage

- Upgrading of existing infrastructure to increase yield or assurance of supply

- Groundwater development

- Small-scale surface water development

- Water trading

- Water re-use

- Desalination of seawater (for coastal towns) or brackish water

- Rainwater harvesting

Because the cost of transport and storage of water plays a major role in the price of water, local water resources, with 
the least storage to reduce losses, should be considered first and the diversification to more independent water resources should also become part of a town's bulk-water supply network in order to reduce the risk of failure in the water supply to the town.

\section{Water conservation and demand management}

As is clear from the significant water losses and the sometimes high water consumption as indicated by the per capita water requirements, the development and effective implementation of a water conservation and water demand management (WC/ WDM) strategy for each town or municipality is essential to reduce the municipal water consumption to acceptable levels. The main elements of such a WC/WDM strategy are:

- Install monitoring devices to measure water consumption at different locations within the distribution network, e.g. at the abstraction point, WTW, pressure or distribution zones, end-users

- Reduce water losses through:

- Leak detection and repair

- Replacement of old distribution network, and

- Pressure control in pipeline network, inter alia

- Reduce water consumption through:

- Public awareness campaigns

- Block tariff and billing system

- The installation of water-efficient fittings, inter alia

In addition, it is recommended that an O\&M plan be developed; the O\&M plan can be used by experienced operating personnel to change and monitor the operational settings and to introduce water restrictions depending upon climatic conditions, as well as pre-empting and planning for the required maintenance to reduce downtime and avoid infrastructure failure.

The Baviaans Local Municipality (LM), for example, has recently completed a water-demand management initiative to reduce water losses. At the same time, a telemetry system was installed to improve the operation and management of the groundwater well-field, which is located about $30 \mathrm{~km}$ outside of the town of Willowmore. This has improved its water-supply reliability and reduced water consumption to avoid imminent water restrictions.

\section{Refurbishment or upgrade of existing infrastructure}

The All Towns Reconciliation Strategy Study has shown that most of the current water-supply problems are not due to a lack of water resources, but rather a result of deteriorated infrastructure or poor O\&M. Often, the best and most cost-effective solution lies in the refurbishment and proper maintenance of existing infrastructure. This was mainly found with groundwater schemes, where boreholes were dismantled or pumps broken, and the municipalities then complained about the 'unreliability' of groundwater.

Similarly, the possibility for reuse of water is compromised by the poor state of most WWTWs (see above). Although reuse of water needs to be considered for future water supply, the reality in most municipalities is that the WWTWs cannot produce the required water quality standard at a reliable level of confidence. Hence, upgrading of the existing infrastructure together with the introduction of proper O\&M measures and management oversight are required to ensure a sustainable and safe water supply.

\section{Groundwater development}

In cases where the above measures are not sufficient to cater for the expected shortfall in water supply, exploration and development of known and new groundwater target areas will have to play an important role. Since there are only a few rivers left that can be further developed with surface water schemes of sufficient size to warrant the huge capital investment, groundwater development is recommended as one of the future options in most of the strategies.

During the recent droughts in the Eastern and Southern Cape many municipalities invested in the development of groundwater emergency schemes and established a number of boreholes for emergency supply. Most of these investments in establishing emergency groundwater supplies have been successful. However, the municipalities are still reluctant to incorporate this groundwater-fed emergency supply into their regular water-supply system, despite its reliability and worth in times of drought being proven. Groundwater supply is still seen as inferior and unreliable, an aspect that the Groundwater Strategy 2010 (DWA, 2010) addresses through awareness campaigns and training of municipal officials.

The information and recommendations from the All Towns Reconciliation Strategies are already utilised for follow-up studies and the potential for groundwater development has already been proven in several cases, e.g.:

- Drilling of exploration and production boreholes has commenced in Middelburg in the Chris Hani District Municipality (DM) and individual yields of up to $12 \mathrm{l} / \mathrm{s}$ have been achieved, which is sufficient to meet the current shortfall and possibly cater for future growth.

- Recently, several high-yielding boreholes of up to $50 \mathrm{l} / \mathrm{s}$ have been drilled in Matatiele in the Alfred Nzo DM, which, if confirmed by further borehole testing, could provide a feasible alternative to the proposed dam on the Kinira River.

The DWA has recently embarked on an exploration drilling programme for towns in the Karoo, mainly within the Cacadu DM. Towns that are in urgent need of additional water supplies were identified in the All Towns Reconciliation Strategies Study and, inter alia, include Jansenville, Rietbron, Steytlerville, Pearston and Paterson. All of these towns are solely relying on local groundwater sources, as the climatic conditions are not favourable for the development of surface water sources.

\section{Conclusions and recommendations}

The All Towns Reconciliation Strategies Study has shown that most of the current water-supply problems and restrictions experienced in many towns and villages could be avoided by proper management of the existing schemes. This must include:

- Effective implementation of water conservation and water demand management measures to reduce losses and wastage

- Proper O\&M, including making provision for an adequate budget for O\&M

- Asset management, to prolong the life of the infrastructure

- Refurbishment of existing infrastructure to reduce losses and wastage

In the recommendations for the strategies developed in the All Towns Reconciliation Strategies Study the use and 
development of groundwater resources is promoted, as DWA often considers it as being the more reliable and feasible option. Local groundwater development is by far more cost effective, especially in the rural areas, than the construction of huge dams with a widespread distribution network to reach widespread, sparsely populated villages. However, this can only be achieved if any infrastructure development projects and or repair measures are combined with skills development and training at all levels within the municipal structures to ensure that the local schemes are operated efficiently, effectively and reliably. Aquifers and municipal groundwater schemes must be managed effectively in accordance with best practice guidelines and groundwater-management frameworks.

It is envisaged that the implementation of these strategies by the municipalities is supported through a steering committee and technical support group at provincial level. However, it is the responsibility of the WSAs to integrate the results and recommendations into their municipal planning instruments and to implement the required interventions to ensure sufficient and sustainable water supply to the people under their jurisdiction.

\section{Acknowledgements}

The study was undertaken as a joint effort of a large team of people who shared the commitment and brought together different expertise and knowledge. We cannot name all here, but want to acknowledge the huge data- and information-gathering effort by the Aurecon teams in Cape Town, East London and Port Elizabeth, as well as the input by Pudja for the Western Cape strategies.

This study would not have been possible without the guidance, support and valuable input by the DWA Directorate: National Water Resource Planning and the DWA Regional Offices in the Eastern Cape and Western Cape. The input into the strategies by the municipalities is much appreciated.

The strategies and reports from this study are available on the website of the Department of Water Affairs: www.dwa.gov. zalDWAStrat!.

\section{References}

DWAF (DEPARTMENT OF WATER AFFAIRS AND FORESTRY, SOUTH AFRICA) (2008) Strategic Framework on Water for Sustainable Growth and Development - Summary Discussion Document. Department of Water Affairs and Forestry, Pretoria, South Africa.
DWA (DEPARTMENT OF WATER AFFAIRS, SOUTH AFRICA) (2009a) Groundwater Resource Information Project (GRIP) Hydrocensus Program, updated 5 February 2009. Department of Water Affairs, Pretoria, South Africa.

DWA (DEPARTMENT OF WATER AFFAIRS, SOUTH AFRICA) (2009b) Development of Reconciliation Strategies for all Towns in the Southern Planning Region: Inception Report. Prepared by Umvoto Africa (Pty) Ltd in association with Aurecon (Pty) Ltd on behalf of the Directorate: National Water Resource Planning. Department of Water Affairs, Pretoria, South Africa.

DWA (DEPARTMENT OF WATER AFFAIRS, SOUTH AFRICA) (2010) Groundwater Strategy 2010. Department of Water Affairs, Pretoria, South Africa.

DWA (DEPARTMENT OF WATER AFFAIRS, SOUTH AFRICA) (2011a) Blue Drop Report 2011 - South African Drinking Water Quality Management Performance. Department of Water Affairs, Pretoria, South Africa.

DWA (DEPARTMENT OF WATER AFFAIRS, SOUTH AFRICA) (2011b) Green Drop Report 2011 - South African Waste Water Quality Management Performance. Department of Water Affairs, Pretoria, South Africa.

DWA (DEPARTMENT OF WATER AFFAIRS, SOUTH AFRICA) (2011c) Database of Water Services Infrastructure for Alfred Nzo DM, Amathole DM, Chris Hani DM and O.R. Tambo DM. DWA Water Services Eastern Cape, South Africa.

DWA (DEPARTMENT OF WATER AFFAIRS, SOUTH AFRICA) (2011d) Development of Reconciliation Strategies for all Towns in the Southern Planning Region: Provincial Summary Report - Eastern Cape. Prepared by Umvoto Africa (Pty) Ltd in association with Aurecon (Pty) Ltd on behalf of the Directorate: National Water Resource Planning. DWA Report No. P RSA 000/00/15311. Department of Water Affairs, Pretoria, South Africa.

DWA (DEPARTMENT OF WATER AFFAIRS, SOUTH AFRICA) (2011e) Development of Reconciliation Strategies for all Towns in the Southern Planning Region: Provincial Summary Report - Western Cape. Prepared by Umvoto Africa (Pty) Ltd in association with Aurecon (Pty) Ltd on behalf of the Directorate : National Water Resource Planning. DWA Report No. P RSA 000/00/15411. Department of Water Affairs, Pretoria, South Africa.

DWA (DEPARTMENT OF WATER AFFAIRS, SOUTH AFRICA) (2012) Groundwater Reserve Determination in the Mzimvubu to Keiskamma WMA - Western Portion: Intermediate GRDM Assessment. Prepared by Umvoto Africa (Pty) Ltd. On behalf of the Directorate: Reserve Requirements, Department of Water Affairs, Pretoria, South Africa.

RSA (REPUBLIC OF SOUTH AFRICA) (2001) Regulations Relating to Compulsory National Standards and Measures to Conserve Water. Notice No. 509 in Regulation Gazette 7079, Government Gazette 22355, dated 8 June 2001.

RIEMANN K, LOUW D, CHIMBOZA N and FUBESI M (2011) Groundwater Management Framework. WRC Report No. 1917/1/11. Water Research Commission, Pretoria, South Africa. 